\title{
Analisis Faktor-Faktor Erosi Tanah, Dan Tingkat Bahaya Erosi Dengan Metode Rusle Di DAS Wai Batu Merah Kota Ambon Provinsi Maluku
}

\author{
Analysis of Soil Erosion Factors and Determination of Erosion Hazard Level With Rusle Method In \\ Wai Batu Merah Watershed In Ambon City Maluku Province
}

\section{Rafel M. Osok*, Silwanus M. Talakua, Ellisa J. Gaspersz}

Jurusan Budidaya Pertanian, Fakultas Pertanian, Universitas Pattimura

J1. Ir. M. Putuhena, Kampus Poka Ambon 97233

Penulis Korespondensi: e-mail: rafael_osok@yahoo.com

\begin{abstract}
The study was conducted in July-October 2016 in the Wai Batu Merah Watershed, Ambon City, Maluku Province with an area of 685.14 ha covering the Village of Batu Merah and parts of Soya Village. This research was carried out with the aim of 1) determining the factors that affect erosion, 2) determining the amount and level of soil erosion hazard, 3) determining the direction of land rehabilitation that is suitable for controlling erosion. The research method is a survey method with a synthetic and analytic approach with flexible observation distance based on land units. The method of determining the amount of erosion is based on the RUSLE method (Renard et al., 1997) and the erosion hazard level based on FAO criteria (FAO, 1979) in Ponce-Hernandez (2004). The results found are 1) Factors affecting erosion in the Wai Batu Merah watershed are rainfall erosivity $(R)$, soil erodibility $(K)$, topography $(L S)$, vegetation $(C)$, soil conservation practice $(P)$. Annual rainfall erosivity factor $=2419.03$ ton.m/ha/cm-rain. For monthly erosivity, the highest erosivity in July is 537.34 ton.m/ha/cm-rain, followed by June at 526.03 tons. $\mathrm{m} / \mathrm{ha} / \mathrm{cm}$ rain. The soil erodibility factor is classified as very low, medium and rather high. Soils with a rather high erodibility level are Thapto-Histic Hydraquents with a K value of 0.380 classified as a rather high class. This means that if other erosion factors are in identical conditions, the potential for land degradation due to erosion in this soil is higher than other soils in the study area. While the low erodibility level is Lithic Udorthents and Typic Fluvaquents with $K$ values of 0.175 and 0.178 , respectively. This indicates that these lands are more resistant to land degradation due to erosion compared to other lands in the Wae Batu Merah watershed. The lowest LS factor value is in land units that have a slope of $0-3 \%$ and 3-8\% with an LS value of 0.25. In land units that have a slope of $8-15 \%$, the LS value is 1.2, in land units with a slope of 15-30\%, the LS value is 4.25, and the land unit with a slope of 30-45\%, has an LS value of 9.50; while land units that have a slope of 45-65\% and $>65 \%$, the LS value is 12.0, as well as the highest LS value in all land units. Vegetation factor or soil management factor with certain plants is settlement value $C=1$; scrub with a value of $C=$ 0.3; and secondary dryland forest with a value of $C=0.005$. While the $P$ value for all land units is 1.00 because there is no found soil conservation action practiced in the Wae Batu Merah watershed. 2). The amount and level of erosion that occurred at the study site was erosion in the classification of slight, moderate, high and very high. The level of severe erosion has an average erosion of 2326.56 tons/ha/year covering an area of 297.06 ha or $43.36 \%$ and is the largest erosion. High erosion rates have an average erosion of 142.1 tons/ha/year covering 249.05 ha or $36.35 \%$. Moderate erosion rates have an average erosion of 30.58 tons/ha/year covering 94.58 ha or 13.8\%. While the level of slight erosion has an average erosion of 5.28 tons/ha/year covering an area of 44.45 ha or $6.49 \%$ of the total area of the study area and is the narrowest level.
\end{abstract}

Keywords: amount and level of erosion, erosion factors, Wai Batu Merah watershed

\section{ABSTRAK}

Penelitian dilaksanakan pada bulan Juli-Oktober 2016 di DAS Wai Batu Merah Kota Ambon Provinsi Maluku dengan luas 685.14 ha yang meliputi Negeri Batu Merah dan sebagian Negeri Soya. Penelitian ini dilaksanakan dengan tujuan: 1) menetapkan faktor-faktor yang mempengaruhi erosi; 2) menetapkan besar dan tingkat bahaya erosi; dan 3) menentuan arahan rehabilitasi lahan yang sesuai untuk mengendalikan erosi. Metode penelitian adalah metode survey dengan pola pendekatan sintetik serta analitik dengan jarak observasi fleksibel berdasarkan unit lahan. Metode penentuan besar erosi adalah berdasarkan metode Revisi USLE (Renard et al., 1997) serta tingkat bahaya erosi berdasarkan kriteria FAO (1979) dalam Ponce-Hernandez (2004). Hasil ditemukan adalah: 1) Faktor-faktor yang mempengaruhi erosi di DAS Wai Batu Merah adalah erosivitas hujan (R), erodibilitas tanah (K), topografi (LS), vegetasi (C), tindakan konservasi tanah (P). Faktor erosivitas hujan tahunan $=2419.03$ ton.m/ha/cm-hujan. Untuk erosivitas bulanan, maka erosivitas tertinggi pada bulan Juli memiliki yaitu sebesar 537.34 ton.m/ha/cm-hujan, 
kemudian diikuti oleh bulan Juni sebesar 526.03 ton.m/ha/cm-hujan. Faktor erodibilitas tanah tergolong tingkat sangat rendah, sedang dan agak tinggi. Tanah-tanah dengan tingkat erodibilitas agak tinggi adalah Thapto-Histic Hydraquents dengan nilai $\mathrm{K}$ sebesar 0,380 tergolong klas agak tinggi. Ini berarti bahwa bila faktor-faktor erosi lain berada dalam kondisi yang identik, maka potensi terjadinya degradasi lahan akibat erosi pada tanah ini lebih tinggi dibandingkan dengan tanah lainnya di daerah penelitian. Sedangkan tingkat erodibilitas rendah adalah Lithic Udorthents dan Typic Fluvaquents dengan nilai K masing-masing 0,175 dan 0,178. Hal ini mengindikasikan bahwa tanah-tanah tersebut lebih resisten terhadap degradasi lahan akibat erosi jika dibandingkan dengan tanah lainnya di DAS Wae Batu Merah. Nilai faktor LS terendah yaitu pada unit lahan yang memiliki kemiringan lereng 0-3\% dan 3-8\% dengan nilai LS sebesar 0,25. Pada unit lahan yang memiliki kemiringan lereng $8-15 \%$, nilai LSnya adalah sebesar 1,2, pada unit lahan dengan kemiringan lereng 15-30\%, nilai LSnya adalah sebesar 4,25, dan unit lahan dengan kemiringan lereng 30-45\%, memiliki nilai LS sebesar 9,50; sedangkan unit-unit lahan yang memiliki kemiringan lereng 45-65\% dan > 65\%, nilai LSnya sebesar 12,0, sekaligus sebagai nilai LS tertinggi pada seluruh unit lahan. Faktor vegetasi atau faktor pengelolaan tanah dengan tanaman tertentu adalah permukiman nilai $\mathrm{C}=1$; semak belukar dengan nilai $\mathrm{C}=0.3$; dan hutan lahan kering sekunder dengan nilai $\mathrm{C}=0.005$. Sedangkan nilai $\mathrm{P}$ untuk semua unit lahan adalah 1.00 , karena belum ada tindakan konservasi tanah yang dipraktekan secara baik di DAS Wae Batu Merah. 2). Besar dan tingkat bahaya erosi yang terjadi di lokasi kajian adalah erosi dengan kategori ringan, sedang, berat dan sangat berat. Tingkat bahya erosi sangat berat memiliki erosi rata-rata sebesar 2326.56 ton/ha/thn seluas 297,06 ha atau 43,36\%, dan merupakan erosi terluas. Tingkat erosi berat memiliki erosi rata-rata sebesar 142.1 ton/ha/thn seluas 249,05 ha atau $36,35 \%$. Tingkat erosi sedang memiliki erosi rata-rata sebesar 30.58 ton/ha/thn seluas 94,58 ha atau $13,8 \%$. Sedangkan tingkat erosi ringan memiliki erosi rata-rata sebesar 5.28 ton/ha/thn seluas 44.45 ha atau 6,49\% dari total luas daerah penelitian, dan merupakan tingkat tersempit.

Kata kunci: besar dan tingkat bahaya erosi, das wai Batu Merah, faktor erosi tanah

\section{PENDAHULUAN}

Setiap kehidupan manusia tidak terlepas dari sumber daya alam yang ada. Tanah merupakan salah satu sumber daya alam yang sangat penting bagi kehidupan manusia. Penggunaan tanah secara baik merupakan hal yang perlu diperhatikan dalam upaya menjamin kelangsungan hidup manusia. Dalam pemanfaatan suatu lahan untuk pertanian maupun non pertanian tanpa adanya usaha pengelolaan yang baik dapat menimbulkan kerusakan lahan dan penurunan produktivitas lahan. Konversi lahan hutan menjadi areal penggunaan lahan lain disadari menimbulkan banyak masalah seperti erosi, penurunan kesuburan tanah, erosi, kepunahan flora dan fauna, banjir, kekeringan dan bahkan perubahan lingkungan global, dan masalah ini bertambah berat dari waktu ke waktu sejalan dengan makin sempitnya luas areal hutan.

Erosi merupakan peristiwa berpindahnya atau terangkutnya material tanah dari suatu tempat yaitu lereng atas oleh media alami dalam hal ini air, kemudian diendapkan pada daerah yang lebih rendah sebagai bahan sedimen atau deposit. Menurut Schwab et al. (1981) erosi terdiri dari dua tipe yaitu erosi geologi (geological erosion) dan erosi dipercepat (accelerated erosion). Erosi geologi adalah proses ketika tanah yang terbentuk dan tanah yang tererosi berada dalam keadaan seimbang, serta sangat sesuai untuk mendukung banyak pertumbuhan tanaman. Sedangkan erosi dipercepat adalah erosi yang terjadi oleh pengaruh manusia yaitu hancurnya agregat-agregat tanah dan mempercepat perpindahan bahan organik serta pertikel-partikel mineral sebagai akibat dari pengolahan tanah yang tidak sesuai dan hilangnya vegetasi alami. Selanjutnya dikatakan bahwa erosi merupakan fungsi dari faktor iklim yaitu curah hujan, tanah, topografi, vegetasi dan manusia (tindakan konservasi tanah dan air).

Lahan pada suatu daerah aliran sungai (DAS) dengan kondisi curah hujan yang tinggi, tanah yang peka erosi, topografi berupa lereng yang panjang dan lebih curam, vegetasi yang terganggu dan tidak adanya tindakan konservasi tanah dan air, akan mengalami erosi lebih tinggi dibandingkan dengan lahan yang memiliki curah hujan yang lebih rendah, tanah yang lebih resisten, lereng lebih datar, vegetasi masih baik disertai adanya tindakan konservasi tanah dan air. Untuk mengkaji masalah pengelolaan sumber daya air dan tanah serta konservasinya secara komprehensif pada suatu wilayah maka pendekatan yang tepat adalah melalui pendekatan DAS (Manik et al., 1996).

Perkembangan pembangunan dan peningkatan jumlah penduduk yang semakin pesat, memerlukan perluasan lahan permukiman untuk tempat tinggal dan lahan pertanian untuk memenuhi kebutuhan hidup masyarakat. Salah satu sumberdaya lahan, yaitu suatu DAS cenderung mendapat tekanan seiring dengan pesatnya pertumbuhan penduduk. Hal tersebut tentunya akan dapat mempengaruhi kualitas suatu DAS.

DAS Wai Batu Merah merupakan salah satu DAS di Kota Ambon yang perlu mendapatkan perhatian khusus karena telah terjadi penurunan kualitas dari DAS tersebut. Penurunan kualitas DAS ini diakibatkan karena semakin meningkatnya jumlah penduduk berakibat timbulnya berbagai masalah yaitu erosi, banjir, dan kekeringan yang semakin meningkat, serta pencemaran air. Data mengenai erosi pada DAS Wai Batu Merah penting sebagai dasar perencanaan rehabilitasi lahan berupa tindakan konservasi tanah yang sesuai. Oleh 
karena itu, perlu dianalisis faktor-faktor erosi tanah, dan tingkat bahaya erosi dengan metode RUSLE di DAS Wai Batu Merah Kota Ambon Provinsi Maluku. Penelitian ini dilaksanakan dengan tujuan: 1) menganalisis faktor-faktor yang mempengaruhi erosi; 2) menetapkan besar dan tingkat bahaya erosi; dan 3) menentuan arahan rehabilitasi lahan yang sesuai untuk mengendalikan erosi.

\section{BAHAN DAN METODE PENELITIAN}

\section{Waktu dan Tempat Penelitian}

Penelitian ini dilaksanakan di DAS Wai Batu Merah Kota Ambon Provinsi Maluku pada bulan Juli sampai Oktober 2016.

\section{Alat dan Bahan Penelitian}

Peralatan yang digunakan dalam penelitian ini adalah Kompas, abney level, altimeter, soil munsell colour chart, soil tester, kartu deskripsi profil, parang, cangkul, indikator $\mathrm{pH}$, bor, meter, pisau lapang, GPS, dan alat tulis menulis. Bahan yang digunakan yaitu $\mathrm{H}_{2} \mathrm{O}_{2}, \mathrm{HCl}$ dan akuades.

\section{Pekerjaan Persiapan}

Pelaksanaan tahap pekerjaan persiapan meliputi : konsultasi pendahuluan dengan para Dosen pembimbing, mencari dan mengumpulkan data tentang daerah penelitian.

a) Membuat Peta Unit Lahan sebagai Peta Kerja.

Peta unit lahan diperoleh dari hasil tumpang tindih (overlay) peta topografi, geologi, jenis tanah dan penggunaan lahan. Peta-peta tersebut diperoleh dari BPDASHL Wae Hapu Batu Merah.

b) Informasi keadaan umum lokasi, mencari dan mengumpulkan data tentang DAS Wai Batu Merah, mempersiapkan alat dan bahan yang akan digunakan serta mempersiapkan administrasi perjalanan dan kebutuhan logistik.

\section{Pekerjaan Lapangan}

Metode yang digunakan adalah survey dengan pola pendekatan sintetik dan jarak observasi fleksibel mengikuti perubahan bentuk fisiografi dan penggunaan lahan pada lokasi penelitian. Pengamatan sifat morfologi tanah dilakukan melalui pengamatan boring, setelah setiap unit lahan telah diwakili dalam boring maka dilakukan pembuatan profil pewakil untuk tiap jenis tanah. Pengukuran faktor-faktor erosi berupa curah hujan, topografi, vegetasi dan tindakan konservasi.

Wawancara dilakukan untuk melengkapi data penelitian. Perihal yang akan ditanyakan meliputi pemanfaatan lahan, frekuensi banjir, debit/sedimentasi sungai pada musim kemarau dan hujan, kearifan lokal (sasi/kewang), dan sebagainya.

\section{Analisis Laboratorium}

Analisis tanah dilakukan di laboratorium tanah, Balai Penelitian Tanah Bogor. Analisis sampel tanah meliputi kandungan bahan organik, dan sifat-sifat fisik tanah (C-organik, tekstur dan permeabilitas profil tanah). Dalam penelitian ini data analisis tanah telah diperoleh dari Balai Pengelolaan DAS dan Hutan Lindung (BPDASHL) Wae Hapu Batu Merah.

\section{Pengolahan Data dan Penyusunan}

Kegiatan pada tahap ini meliputi: menetapkan klasifikasi jenis tanah, menghitung faktor erosivitas hujan (R), erodibilitas tanah (K), topografi (LS), vegetasi/tanaman $(C)$ dan tindakan konservasi tanah $(\mathrm{P})$. Menentukan besar dan tingkat bahaya erosi (A) (ton/ha/thn) dengan metode RUSLE Besarnya erosi di lokasi penelitian dianalisis untuk setiap unit lereng berdasarkan arah aliran (Morgan, 1993; Renard et al., 1997) dengan menggunakan persamaan umum kehilangan tanah RUSLE (Revised Universal Soil Loss Equation) oleh Renard et al. (1997) sesuai persamaan berikut ini:

$$
\mathrm{A}=\mathrm{R} \times \mathrm{K} \times \mathrm{LS} \times \mathrm{C} \times \mathrm{P} .
$$

Tahapan berikutnya adalah menentukan arahan rehabilitasi lahan serta membuat peta-peta hasil penelitian.

\section{HASIL DAN PEMBAHASAN}

\section{Faktor-Faktor Erosi DAS Wai Batu Merah}

Berdasarkan hasil analisis dari Rumus maka erosivitas hujan tahunan DAS Wae Batu Merah adalah 2419.03 ton.m/ha/cm-hujan. Untuk erosivitas bulanan, maka erosivitas tertinggi pada bulan Juli memiliki yaitu sebesar 537.34 ton.m/ha/cm-hujan, kemudian diikuti oleh bulan Juni sebesar 526.03 ton.m/ha/cm-hujan. Ini dapat dijelaskan bahwa, curah hujan yang jatuh sebesar $10 \mathrm{~mm}$ yang jatuh pada areal seluas 1 ha akan memiliki energi penghancur permukaan tanah (soil detachment energy by rainfall) masing-masing sebesar 2419.03 ton.m secara tahunan, dan 537,34 ton.m dan 526.03 ton.m. Hal ini mengindikasikan bahwa kemampuan potensial hujan untuk menyebabkan degradasi tanah akibat erosi sangat tinggi pada bulan-bulan tersebut, sehingga sangat berpotensi untuk terjadinya bahaya erosi, banjir dan longsor di DAS Wae Batu Merah. Sedangkan nilai erosivitas hujan terendah adalah pada bulan November sebesar 33,11 ton.m/ha/cm-hujan. Ini berarti bahwa, curah hujan yang jatuh sebesar $10 \mathrm{~mm}$ yang jatuh pada areal seluas 1 ha akan memiliki energi penghancur permukaan tanah sebesar 33.11 ton.m. Hal ini mengindi-kasikan bahwa kemampuan potensial hujan untuk menyebabkan degradasi tanah akibat erosi dan longsor serta banjir di DAS Wae Batu Merah pada bulan tersebut sangat rendah. Menurut Anthony (2001), curah hujan merupakan faktor iklim yang paling besar menyebabkan erosi. Air hujan memiliki berat sekitar 
800 kali lebih berat dibanding udara, setengah hingga sepertiga berat batuan dan sama berat dengan lapisan atas tanah yang terlepas. Ketika mengalir, air itu dapat memindahkan massa tanah, sehingga partikel tanah dapat lepas dengan mudah dan momen hujan paling merusak adalah ketika suatu tetesan air memukul tanah

Penentuan nilai K berdasarkan jenis tanah. Hasil penelitian menunjukkan bahwa jenis tanah yang terdapat di daerah penelitian adalah Typic Fluvaquents, Thapto-Histic Hydraquents, Lithic Haprendolls, Lithic Udorthents, Lithic Eutrudepts dan Typic Rhodudults. Berdasakan luasan, maka jenis tanah Lithic Eutrudepts merupakan jenis tanah yang memiliki distribusi paling dominan di daerah penelitian dengan luasan 323,49 ha atau 47,21 persen, diikuti oleh jenis tanah Typic Rhodudults seluas 238,47 ha atau 34,81 persen dan Lithic Haprendolls seluas 71,78 ha atau 10,48 persen dari total luas daerah penelitian. Sedangkan jenis tanah yang memiliki penyebaran sempit antara lain : ThaptoHistic Hydraquents dengan luasan 0,53 ha atau 0,08 persen, diikuti oleh jenis tanah Lithic Udorthents (Litosol) seluas 14,15 ha atau 2,07 persen dan jenis tanah Typic Fluvaquents (Aluvial) seluas 36,73 ha atau 5,36 persen dari total luas daerah penelitian. Hasil analisis menunjukkan erodibilitas tanah dengan tingkat sangat rendah, sedang dan agak tinggi. Tanah-tanah dengan tingkat erodibilitas agak tinggi adalah ThaptoHistic Hydraquents dengan nilai K sebesar 0,380. Untuk tingkat sedang adalah Lithic Eutrudepts, Lithic Haprendolls dan Typic Rhodudults, dengan nilai K masing masing 0,22;0,28 dan 0,225. Sedangkan tingkat erodibilitas rendah adalah Lithic Udorthents dan Typic Fluvaquents dengan nilai $\mathrm{K}$ masing-masing 0,175 dan 0,178 . Ini berarti bahwa tanah-tanah di DAS Wai Batu Merah dengan nilai K yang lebih tinggi, akan berpotensi menyebabkan degradasi tanah akibat erosi lebih tinggi dibandingkan dengan tanah-tanah dengan nilai $\mathrm{K}$ yang lebih rendah jika faktor-faktor erosi lain berada dalam kondisi yang identik. Menurut Arsyad (2006), faktor tanah sangat berpengaruh terhadap erosi, dan kemudahan suatu tanah untuk menimbulkan erosi disebut erodibilitas. Jika pada tingkat energi yang sama, tanah yang mempunyai nilai erodibilitas tinggi akan lebih mudah mengalami erosi dari tanah dengan nilai erodibilitas rendah.

Hasil kajian menunjukkan bahwa nilai faktor panjang dan kemiringan lereng (LS) pada suatu unit lahan di DAS Wae Batu Merah, bervariasi sesuai kemiringannya. Nilai LS terendah yaitu pada unit lahan yang memiliki kemiringan lereng $0-3 \%$ dan 3-8\% dengan nilai LS sebesar 0,25. Pada unit lahan yang memiliki kemiringan lereng 8-15\%, nilai LSnya adalah sebesar 1,2, pada unit lahan dengan kemiringan lereng $15-30 \%$, nilai LS-nya adalah sebesar 4,25 , dan unit lahan dengan kemiringan lereng 30-45\%, memiliki nilai LS sebesar 9,50; sedangkan unit-unit lahan yang memiliki kemiringan lereng $45-65 \%$ dan $>65 \%$, nilai LS-nya sebesar 12,0, sekaligus sebagai nilai LS tertinggi pada seluruh unit lahan. Berdasarkan luasannya, maka unit lahan yang memiliki kemiringan lereng 15-30\% dengan nilai LS sebesar 4,25, merupakan LS terluas yaitu 188.51 ha atau $27.51 \%$, jika dibandingkan dengan luasan nilai LS lainnya. Sedangkan unit lahan yang memiliki kemiringan lereng > 65\% dengan nilai LS sebesar 12 merupakan nilai LS tersempit yaitu 8.83 ha atau $1.29 \%$ jika dibandingkan dengan nilai LS lainnya di daerah penelitian. Menurut Anthony (2001), lahan yang datar biasanya lebih stabil, tetapi terjadi peningkatan kehilangan tanah dengan cepat bila kemiringan bertambah menjadi $2 \%-5 \%$. Pada kemiringan lereng $10 \%$, erosi akan meningkat menjadi delapan kali lebih tinggi, dan pada kemiringan lereng $15 \%$, erosi tanah telah meningkat lagi.

Beberapa faktor pengelolaan tanah dengan tanaman tertentu yang ditemukan di seluruh unit lahan pada lokasi penelitian. adalah permukiman nilai $\mathrm{C}=1$; semak belukar dengan nilai $\mathrm{C}=0,3$; dan hutan lahan kering sekunder dengan nilai $\mathrm{C}=0,005$. Sedangkan nilai $\mathrm{P}$ untuk semua unit lahan adalah 1 , karena belum ada tindakan konservasi tanah yang dipraktekan secara baik di DAS Wae Batu Merah. Nilai C penggunaan lahan hutan lahan kering sekunder memiliki areal yang lebih sempit yaitu 61,46 ha atau $8,97 \%$ dari total luas DAS. Areal dengan nilai $\mathrm{C}$ terluas adalah pada penggunaan lahan permukiman seluas 408.26 ha atau $59,59 \%$. Nilai $\mathrm{C}$ untuk penggunaan lahan semak belukar adalah 215.42 ha atau $31.44 \%$ dari total luas daerah penelitian DAS Wae Batu Merah. Menurut Arsyad (2006), nilai $\mathrm{C}$ dan $\mathrm{P}$ merupakan nisbah besarnya erosi dari suatu lahan dengan vegetasi dan tindakan konservasi tertentu terhadap besar erosi pada lahan yang sama tanpa tanaman/vegetasi yang diolah searah lereng, sehingga semakin besar nilai $\mathrm{C}$ dan $\mathrm{P}$ akan berpotensi menyebabkan erosi lebih tinggi.

\section{Besar dan Tingkat Bahaya Erosi DAS Wai Batu Merah}

Hasil penentuan tingkat bahaya erosi berdasarkan besar erosi pada suluruh unit lahan di DAS Wae Batu Merah, seperti disajikan pada Tabel 1 dan Gambar 1, menunjukkan bahwa tingkat bahaya erosi yang terjadi di lokasi kajian adalah erosi dengan kategori ringan, sedang, berat dan sangat berat. Hasil analisis menunjukkan bahwa tingkat bahya erosi sangat berat memiliki erosi rata-rata sebesar 2326,56 ton/ha/thn seluas 297.06 ha atau $43,36 \%$, dan merupakan erosi terluas. Tingkat erosi berat memiliki erosi rata-rata sebesar 142.1 ton/ha/thn seluas 249,05 ha atau $36,35 \%$. Tingkat erosi sedang memiliki erosi rata-rata sebesar 30,58 ton/ha/thn seluas 94,58 ha atau $13,8 \%$. Sedangkan tingkat erosi ringan memiliki erosi rata-rata sebesar 5,28 ton/ha/thn seluas 44,45 ha atau $6,49 \%$ dari total luas daerah penelitian, dan merupakan tingkat tersempit.

Dari hasil tersebut, dapat dijelaskan bahwa, faktor erosivitas hujan, erodibilitas tanah, topografi penggunaan lahan dan tindakan konservasi berpengaruh terhadap tingkat bahaya erosi. Sementara faktor yang dominan pengaruhnya adalah erodibilitas tanah, topografi dan vegetasi penutup. 
Tabel 1. Besar dan tingkat bahaya erosi DAS Wae Batu Merah

\begin{tabular}{cccccc}
\hline No. & Tingkat Bahaya Erosi & $\begin{array}{c}\text { Kisaran Besar Erosi } \\
\text { (ton/ha/thn) }\end{array}$ & $\begin{array}{c}\text { Besar Erosi rata-rata } \\
\text { (ton/ha/thn) }\end{array}$ & Luas (Ha) & $\%$ \\
\hline 1. & Ringan & $0,67-11,57$ & 5,28 & 44,45 & 6,49 \\
2. & Sedang & $20,11-40,82$ & 30,58 & 94,58 & 13,80 \\
3. & Berat & $50,80-195,94$ & 142,10 & 249,05 & 36,35 \\
4. & Sangat berat & $229,81-8127,94$ & 2326,56 & 297,06 & 43,36 \\
\hline \multicolumn{7}{r}{} & Total & & & 685,14 & 100,00 \\
\hline
\end{tabular}

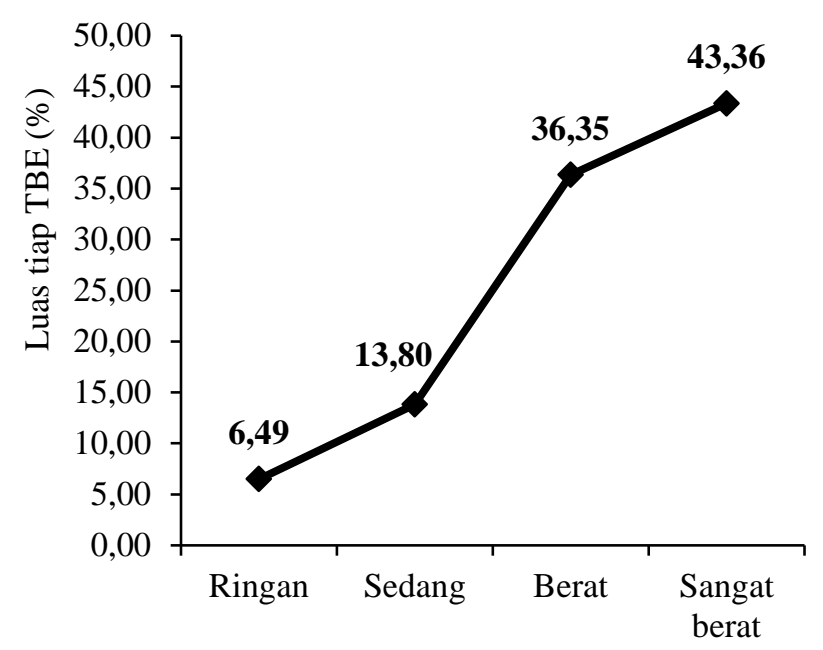

Tingkat bahaya erosi

Gambar 1. Luas Tingkat Bahaya Erosi (\%) di DAS Wae Batu Merah

Hal ini sejalan dengan hasil penelitian Talakua dan Talakua (2006) bahwa pengaruh faktor erodibilitas tanah, faktor topografi dan faktor pengelolaan tanaman terhadap kerusakan tanah akibat erosi di DAS Wai Riuapa adalah nyata pada tingkat kepercayaan 95\% (Pvalue $\left.=0,000^{*}\right)$. Dikuatkan dengan hasil penelitian Talakua (2016; 2009) bahwa di Kecamatan Kairatu, vegetasi yang masih alami seperti hutan primer memiliki degradasi lahan akibat erosi rata-rata 1,69 ton/ha/thn (tergolong ringan), sementara lahan marginal hasil konversi seperti semak belukar mengalami erosi rata-rata 285,57 ton/ha/thn (sangat berat)

Hasil penelitian ini menunjukkan bahwa pesatnya pertumbuhan penduduk yang cepat telah mendorong pertumbuhan permukiman yang cepat pula, sehingga terjadi konversi lahan dari penggunaan hutan dan lainnya menjadi lahan permukiman secara cepat. Menurut Hudson (1992 dikutip FAO, 1999) ketika populasi penduduk perdesaan meningkat, terjadi perluasan areal perdesaan, maka semakin banyak permukiman perdesaan pindah bergeser ke lahan-lahan curam. Adanya permukiman dan pertanian pada lerenglereng yang curam akan menimbulkan dan memperlebar berbagai persoalan seperti masalah sosial, ekonomi dan lingkungan seperti erosi. Menurut Symeonakis et al. (2004) penebangan hutan (deforestasi) menjadi penyebab meningkatnya laju aliran permukaan sejak vegetasinya dihilangkan.

\section{Arahan Rehabilitasi Lahan DAS Wai Batu Merah}

Arahan rehabilitasi lahan DAS merupakan langkah penerapan kaidah-kaidah konservasi tanah, air dan vegetasi yang disesuaikan dengan permasalahan yang ada di DAS Wai Batu Merah (Gambar 3) dengan mempertimbangkan faktor-faktor yang mempengaruhi erosi ( R, K, LS, C, P), tingkat bahaya erosi, nilai CPmaksimum, besar erosi yang masih dapat ditoleransikan serta memperhatikan kondisi penggunaan lahan saat ini. Arahan ini secara khusus dilakukan untuk meningkatkan nilai faktor $\mathrm{C}$ dan $\mathrm{P}$ melalui perbaikan tutupan lahan sehingga mampu mengintersep energi pukulan butir hujan dengan canopi yang lebih rapat, memperbaiki agregasi tanah dengan pembentukan struktur tanah yang lebih granuler, sehingga meningkatkan infiltrasi dan mengurangi aliran permukaan. Disamping untuk melestarikan fungsi DAS sebagai pengatur tata air dan perlindungan ekosistim DAS, arahan penggunaan lahan di daerah penelitian adalah: meningkatkan persentase tutupan permukaan lahan melalui vegetasi hutan dan buah-buahan, khususnya pada penggunaan lahan semak belukar dan hutan lahan kering sekunder baik di dalam kawasan hutan lindung maupun kawasan lindung diluar kawasan hutan dan budidaya sehingga mencapai kecukupan luas kawasan hutan minimal 30\% dari luas DAS.

\section{Hutan Lahan Kering Sekunder}

Penggunaan lahan hutan lahan kering sekunder yang menempati $8.97 \%$ dari total luas DAS Wae Batu Merah tersebar pada bagian hulu dan tengah DAS Wai Batu Merah dengan kemiringan lereng agak curam hingga curam. Oleh sebab itu arahan perbaikan pada penggunaan lahan pada hutan lahan kering sekunder khususnya pada unit lahan L1dG5, L1dH5, L2dE5, L2dG5, L2dH5, L3dE5, L3dG5, L3dH5, L4dE5, L4dG5, L5dE5, L5dG5 yang mempunyai kemiringan lereng agak curam hingga curam yaitu menambah (pengkayaan) kerapatan vegetasi dengan pohon kehutanan. Pola arahan ini dimaksudkan untuk menurunkan nilai vegetasi (nilai $\mathrm{C}$ untuk hutan sekunder) dari 0,005 menjadi 0,001 untuk hutan primer sehingga besar dan tingkat bahaya erosi dapat dipertahankan bahkan dikurangi, sehingga mampu mengurangi volume aliran permukaan dan meningkatkan retensi air hujan ke dalam tanah (meningkatkan simpanan air tanah). 


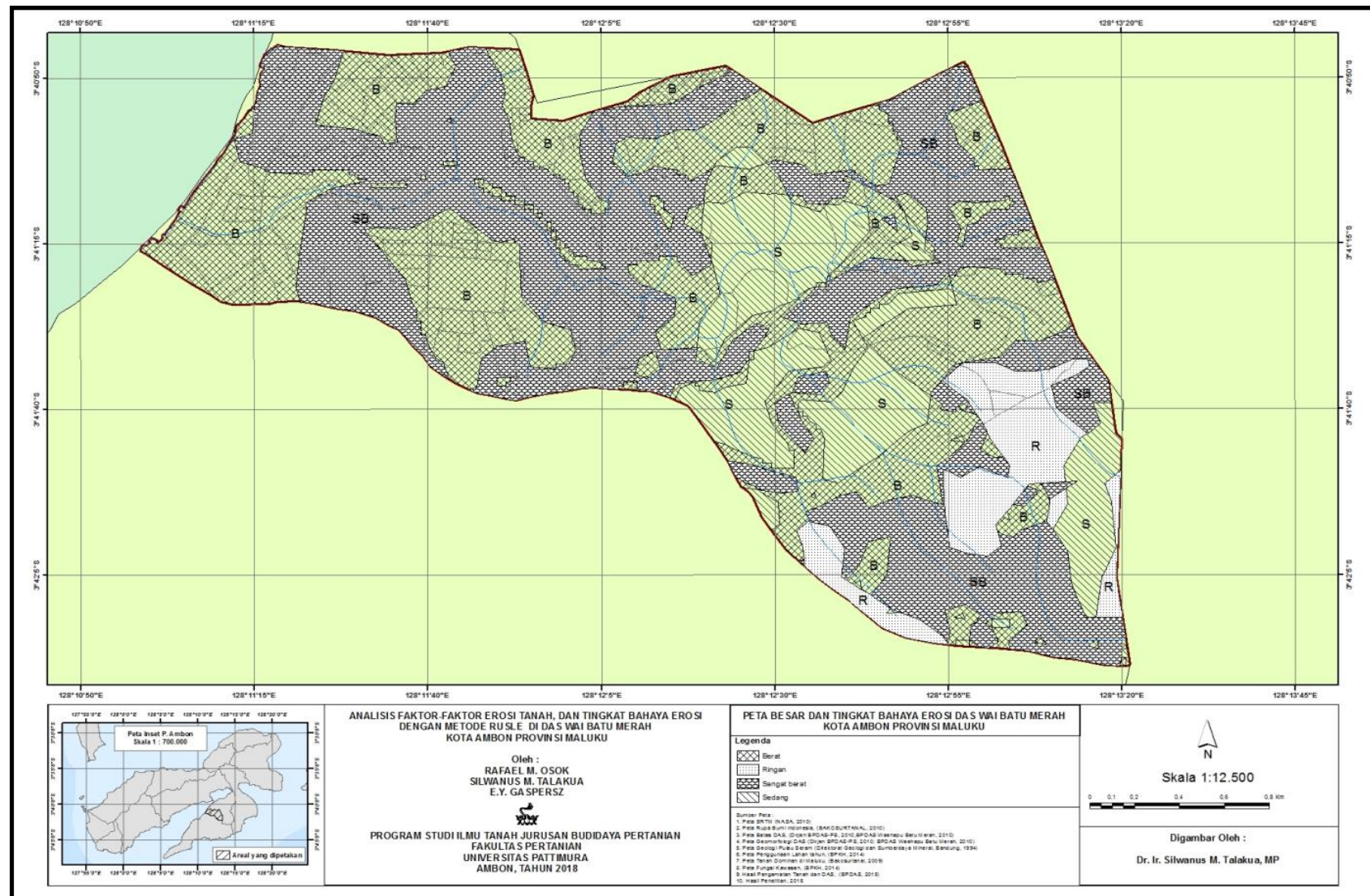

Gambar 2. Peta tingkat bahaya erosi di DAS Wai Batu Merah

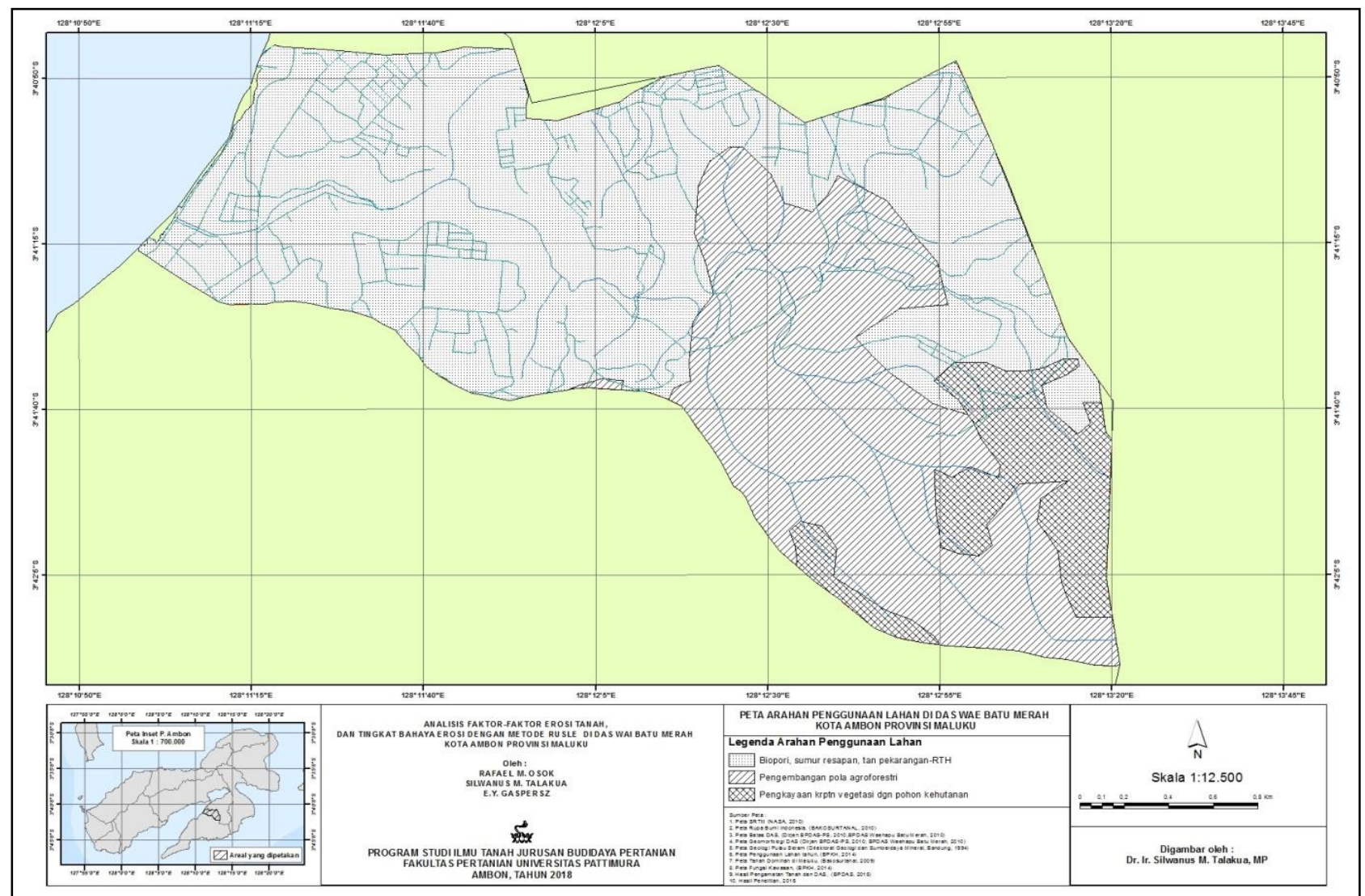

Gambar 3. Peta arahan rehabilitasi lahan di DAS Wai Batu Merah 


\section{Semak Belukar}

Lahan-lahan terbuka yang didominasi penggunaan lahan semak belukar yang menempati masing-masing 31,44\% dari total luas DAS Wai Batu Merah harus dikembangkan melalui pola agroforestri mengingat penyebaran penggunaan lahan ini dekat dengan permukiman penduduk. Pola arahan ini dimaksudkan untuk menurunkan nilai vegetasi (nilai $\mathrm{C}$ untuk semak belukar ) dari 0,3 menjadi 0,2-0,1untuk kebun campuran kerapatan sedang sampai rapat, dengan nilai $\mathrm{P}$ (tanpa konservasi) dari 1,00 menjadi 0,5-0,1 untuk penanaman tanaman penutup tanah rendah pada tanaman perkebunan kerapatan sedang sampai tinggi, sehingga besar dan tingkat bahaya erosi dapat dikurangi dari sangat berat sampai sedang menjadi sedang sampai ringan. Pola ini, selain dapat mengurangi volume aliran permukaan dan meningkatkan simpanan air tanah, juga dapat memberi manfaat ekonomi bagi masyarakat. Arahan perbaikan ini meliputi unit lahan lahan LObD4, L0bG4, L0bH4, LOdG4, L0dH4, L1bD4, L1bG4, L1bH4, L1dG4, L1dH4, L2bD4, L2bG4, L2bH4, L2dE4, L2dG4, L2dH4, L3bD4, L3bG4, L3bH4, L3dE4， L3dG4， L3dH4， L4bD4， L4bG4， L4dE4, L4dG4, L4dH4, L5dE4, untuk penggunaan lahan semak belukar.

\section{Permukiman}

Daerah penelitian didominasi oleh penggunaan lahan permukiman yang menempati masing-masing $59.59 \%$ dari total luas DAS Wae Batu Merah yang meliputi satuan lahan : L0aA1, L0bD1, L0bG1, L0bH1, L0dD1, L0dG1, L0dH1, L1aA1, L1bD1, L1bG1, L1bH1, L1dB1, L1dD1，L1dG1，L1dH1，L2bD1, L2bG1, L2bH1, L2dD1, L2dG1, L2dH1, L3bD1, L3bE1, L3bG1, L3bH1, L3dD1, L3dG1, L3dH1, L4bD1，L4bG1，L4bH1，L4dD1，L4dG1，L4dH1, L5bD1, L5bG1, L5dD1. Kawasan permukiman umumnya merupakan bangunan dengan konstruksi permanen dan tergolong permukiman padat dengan lahan pekarangan yang sempit sehingga kurang berfungsi sebagai daerah resapan. Arahan perbaikan pada kawasan permukiman antara lain : secara teknis dengan membuat biopori atau sumur resapan individual, serta secara vegetatif dengan menanaman tanaman pekarangan untuk meningkatkan ruang terbuka hijau (RTH). Pola arahan ini dimaksudkan untuk menurunkan nilai vegetasi (nilai $\mathrm{C}$ untuk permukiman ) dari 1,0 menjadi 0,4-0,1 untuk kebun campuran kerapatan sedang sampai rapat berupa tanaman pekarangan, dengan nilai $\mathrm{P}$ (tanpa konservasi) dari 1,00 menjadi 0,50,1 untuk penanaman tanaman penutup tanah rendah pada tanaman perkebunan kerapatan sedang sampai tinggi, sehingga besar dan tingkat bahaya erosi dapat dikurangi dari sangat berat sampai sedang menjadi sedang sampai ringan. Pola ini dapat mengintersep air hujan yang jatuh ke permukaan tanah dengan energi yang tidak merusak, mengurangi volume aliran permukaan, memperbesar simpanan air yang masuk ke dalam tanah pada wilayah permukiman.

\section{PENUTUP}

1. Faktor-faktor yang mempengaruhi erosi di DAS Wai Batu Merah adalah : erosivitas hujan tahunan = 2419,03 ton.m/ha/cm-hujan. Nilai erodibilitas tanah dengan tingkat sangat rendah, sedang dan agak tinggi. Tanah-tanah dengan tingkat erodibilitas agak tinggi adalah Thapto-Histic Hydraquents dengan nilai $\mathrm{K}$ sebesar 0,380. Untuk tingkat sedang adalah Lithic Eutrudepts, Lithic Haprendolls dan Typic Rhodudults, dengan nilai $\mathrm{K}$ masing masing 0,$22 ; 0,28$ dan 0,225 . Sedangkan tingkat erodibilitas rendah adalah Lithic Udorthents dan Typic Fluvaquents dengan nilai K masing-masing 0,175 dan 0,178 . Nilai faktor panjang dan kemiringan lereng (LS) bervariasi sesuai kemiringannya. Faktor topografi (LS) pada lereng $0-3 \%$ dan $3-8 \%=0,25$, pada lereng $8-15 \%=1,2$, pada lereng $15-30 \%=4,25$, pada lereng $30-45 \%=$ 9,50 ; sedangkan lereng $45-65 \%$ dan $>65 \%=12,0$. Beberapa faktor vegetasi semak belukar $(\mathrm{C}=0,3)$; hutan lahan kering sekunder $(\mathrm{C}=0,005)$, permukiman $(\mathrm{C}=1,0)$.Sedangkan nilai $\mathrm{P}$ untuk semua unit lahan adalah 1,00, karena belum ada tindakan konservasi tanah yang dipraktekan secara baik.

2. Besar dan Tingkat Bahaya Erosi : tingkat bahya erosi sangat berat memiliki erosi rata-rata sebesar 2326,56 ton/ha/thn seluas 297.06 ha atau $43,36 \%$, dan merupakan erosi terluas. Tingkat erosi berat memiliki erosi rata-rata sebesar 142,1 ton/ha/thn seluas 249,05 ha atau $36,35 \%$. Tingkat erosi sedang memiliki erosi rata-rata sebesar 30,58 ton/ha/thn seluas 94,58 ha atau $13,8 \%$. Sedangkan tingkat erosi ringan memiliki erosi rata-rata sebesar 5,28 ton/ha/thn seluas 44,45 ha atau $6,49 \%$ dari total luas daerah penelitian, dan merupakan tingkat tersempit.

\section{DAFTAR PUSTAKA}

Anthony, F.J. 2001. Soil Erosion and Conservation. Seafriends Marine Conservation and Education Centre. 7 Goat Island Rd. Leigh R.D.5. New Zealand.

Arsyad, S. 2006. Konservasi Tanah Dan Air. Departemen Tanah Fakultas Pertanian IPB. IPB Press. Bogor.

FAO. 1999. New Concepts and Approaches to Land Management in The Tropics with Emphasis on Steeplands. FAO Soil Bulletin 75. Land and Water Publication Series. Land and Water Development Division.

Manik, K.E.S., Afandi, dan S.B. Yuwono. 1996. Karakterisasi beberapa sub-sub DAS Kuripan 
Kotamadya Bandar Lampung. Jurnal Tanah Tropika Tahun II No. 2. hal 94-99.

Morgan. 1993. Soil Erosion and Conservation. Longman Scientific and Technical. John Wiley and Sons. New York.

Ponce-Hernandez. 2004. Assessing Carbon Stock and Modelling Win-Win Scenarios of Carbon Sequestration through Land Use Changes. Land and Water Development Divison.

Renard, K.G., G.R. Foster, G.A. Weesies, D.K. McCool, and C.D. Yoder. 1997. Predicting Soil Erosion by Water: A Guide to Conservation Planning with the Revised Soil Loss Equation (RUSLE). U.S. Department of Agriculture, Agricalture Handbook No. 703, 384 pp.

Schwab. G.O., Richard. Frevert, Talcott. W. Edminster, Kenneth. K. Barnes. 1981. Soil and Water Conservation Engineering. Third Edition. John Willey and Sons New York. Chichester. Brisbone Toronto.

Symeonakis. E, S. Koukoulas, A. Calvo-Cases, E. Arnau-Rosalen, and I. Makris. 2004. A Landuse
Change and Land Degradation Study In Spain and Greece Using Remote Sensing and GIS. Departamento de Geografía, Universidad de Valencia, Av. Blasco Ibáñez 28, Valencia 46010, Spain - Dept. of Geography, University of the Aegean, Mytilene 81100, Greece.

Talakua, S.M. 2016. Degradasi Lahan Metode Analisis dan Aplikasinya dalam Penggunaan Lahan. Plantaxia. Yogyakarta.

Talakua, S.M. dan M.W. Talakua. 2006. Evaluasi Kerusakan Tanah Dan Cara Pengendaliannya Di Daerah Aliran Sungai Wae Riuapa Kecamatan Kairatu Propinsi Maluku. Laporan Penelitian Dosen Muda. Fakultas Pertanian. Universitas Pattimura.

Talakua, S.M. 2009. Pengaruh penggunaan lahan terhadap kerusakan tanah karena erosi di Kecamatan Kairatu Kabupaten Seram Bagian Barat Provinsi Maluku. Jurnal Budidaya Pertanian 5: 27-34. 